\title{
Factors influencing survival after balloon atrial septostomy for complete transposition of great arteries
}

\author{
RANJIT LEANAGE, „ ALDO AGNETTI, GERALD GRAHAM, JAMES TAYLOR, \\ FERGUS J MACARTNEY†
}

From The Departments of Paediatric Cardiology and Clinical Physiology and the Thoracic Unit, The Hospital for Sick Children, Great Ormond Street, London

SUMMARY Despite balloon atrial septostomy within the first days of life, some patients with complete transposition of the great arteries die before reaching elective definitive surgery in the second six months of life. To discover why, we analysed the fate of 144 patients who had balloon atrial septostomy after 1966, using a modified logrank survival test with multivariate capability. Patients were withdrawn 'alive' on reaching definitive surgery.

The following largely independent factors were associated with a statistically significant excess mortality: pulmonary hypertension, the presence and size of a ventricular septal defect or persistent ductus arteriosus, relative anaemia, absence of left ventricular outflow tract obstruction, low arterial oxygen saturation, aortic stenosis and coarctation, and balloon atrial septostomy between 1 week and 1 month of life.

Those of the above factors which can be determined at balloon atrial septostomy or at routine cardiac catheterisation at 3 months of age were then introduced into discriminant function analysis on survival to 6 months. Hence the probability of any individual patient dying in the first six months was calculated, allowing for these factors. This prediction was correct in 76 per cent of the patients studied. By offering earlier definitive correction to patients thus identified as being at high risk of premature death, it should prove possible to reduce overall mortality in transposition of the great arteries.

Balloon atrial septostomy ${ }^{1}$ has dramatically improved life expectancy for infants with complete transposition of the great arteries. Even so, many infants die before reaching definitive surgery, ${ }^{2-9}$ frequently in an unexpected and unexplained manner. ${ }^{2} 3$ If it were possible to predict which patients were at risk of dying, the overall mortality from transposition of the great arteries might be reduced by earlier definitive surgery in selected patients. This study was carried out in order to determine whether such selection was feasible.

\section{Subjects and methods}

One hundred and forty-four patients from the United Kingdom with complete transposition of the great arteries underwent balloon atrial septostomy between 6 December 1966 and 1 June 1978 at

*British Heart Foundation Junior Research Fellow. tFJM is supported by the British Heart and Vandervell Foundations. Received for publication 14 October 1980.
The Hospital for Sick Children, Great Ormond Street. Only patients with atrioventricular concordance and ventriculoarterial discordance ${ }^{10}$ were included; patients with imperforate valves or common atrioventricular orifice were excluded. The first 80 of these patients formed the basis of a previous report by Tynan. ${ }^{2}$

Each case record was reviewed, and the data possibly relevant to survival and obtainable before definitive surgery were extracted. These are listed in Table 1. The information was punched on to cards, and processed at the University of London Computer Centre. Unless the angiocardiographic appearances suggested a defect not more than 2 to $3 \mathrm{~mm}$ in diameter, a ventricular septal defect was classified as large if the left ventricular right ventricular systolic pressure ratio was above $0 \cdot 8$, and a persistent ductus arteriosus was classified as large if the pulmonary artery/aortic systolic pressure ratio was above $0 \cdot 8$. The pressure data used were, if possible, those obtained at the second cardiac 
Table 1 Initial coding of variables

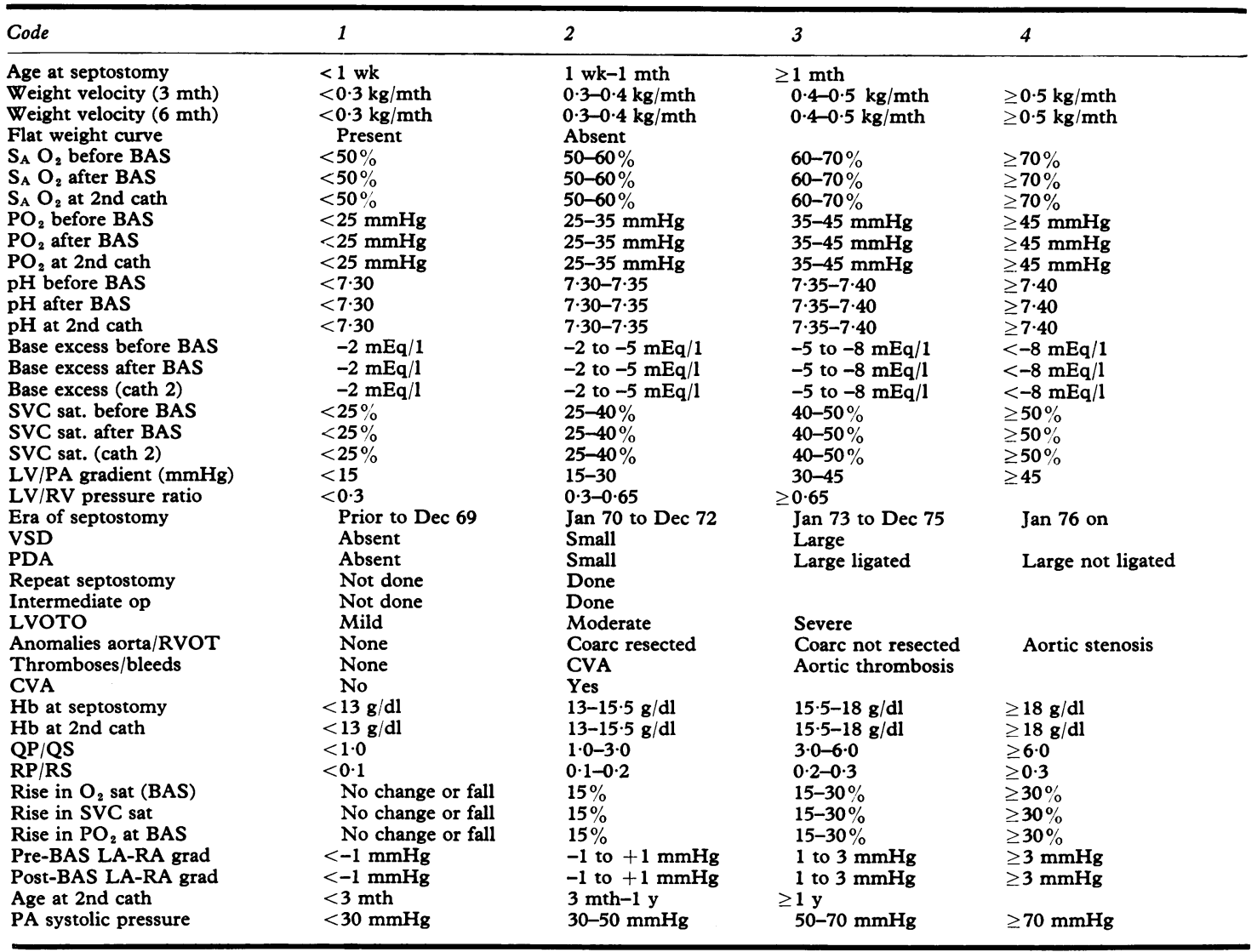

Abbreviations: BAS, balloon atrial septostomy; coarc, coarctation; CVA, cerebrovascular accident; Hb, haemoglobin concentration; $L V$, left ventricle; LVOTO, left ventricular outflow tract obstruction; op, operation; PDA, persistent ductus arteriosus; $S_{A} O_{2}$, systemic arterial oxygen saturation; VSD, ventricular septal defect; LA, left atrium; RA, right atrium; SVC, superior vena cava; PA, pulmonary artery; cath, catheterisation.

catheterisation, which took place in 98 patients, and well after the newborn period. In the first few days of life, left ventricular presures are occasionally high even in the absence of a ventricular septal defect, persistent ductus arteriosus, or left ventricular outflow tract obstruction.

Left ventricular outflow tract obstruction was regarded as absent if the systolic gradient between left ventricle and pulmonary artery was less than $15 \mathrm{mmHg}$, mild if the gradient was 15 to $25 \mathrm{mmHg}$, and moderate if the gradient was 25 to $60 \mathrm{mmHg}$. It was regarded as severe if the left ventricular pressure was suprasystemic, or systemic with a gradient above $60 \mathrm{mmHg}$, or if the angiocardiographic appearances showed unequivocal and distinct subvalvular obstruction. Patients who had a left ventricular systolic pressure less than $40 \mathrm{mmHg}$, those whose pulmonary arterial pressure had not been measured, and those who died before they could be re-catheterised, were graded as having no left ventricular outflow tract obstruction. Those in whom the initial left ventricular pressure was higher than the right but who died without the pulmonary arterial pressure having been measured, were graded according to the angiographic and/or necropsy findings.

Data transformations were calculated by an initial Fortran processing programme which calculated time periods in days, coded continuous variables, and transformed discontinuous variables where necessary, calculated oxygen contents and pulmonary and systemic resistance ratios, and fitted either quadratic and cubic equations (of possible) to the weights at different times, so as to produce a weight curve. These weight curves were output onto microfilm using the Dimfilm package and reviewed visually. At least one of the cubic and quadratic fits was always acceptable and was ac- 
cordingly selected. Weight velocities were then computed by differentiation at three and six months, and the presence of maxima in the weight curves before death or surgery (that is a subsequent period of weight loss) detected by double differentiation. While it was felt highly desirable to calculate absolute pulmonary and systemic flows and resistance, the lack of a measured oxygen uptake in most patients, together with lack of a body length (from which to determine surface area) in many, led us to calculate only ratios between flows and resistances. In determining oxygen content, allowance was made for dissolved oxygen in the plasma $(0.3 \mathrm{ml} / 100 \mathrm{ml}$ per $100 \mathrm{mmHg})$. The coding of derived variables is shown in Table 1 .

Three separate statistical techniques were then applied to the disc file thereby created from the raw data.

First, the relation of coded variables with survival was analysed by a modification of the MantelHaenszel test ${ }^{11}$ originally developed for analysis of cancer survival. ${ }^{12}$ Approximately 500 runs of this programme were carried out, so as to establish what variables had a broadly independent relation with survival. In any particular run, the effect of up to four variables was studied. If the value of any of those four variables in a particular patient was unknown, that patient had to be excluded from the analysis, that is missing values were dealt with by casewise deletion. Care was taken to ensure that casewise deletion was not the spurious reason for abolition of the effect of one variable when adjusted to allow for a second.

Survival time was calculated up to the date when the patient had last been alive, except for patients reaching definitive surgery who were treated as though they had last been seen alive on that day.

Before entry into the remaining parametric statistical tests, discontinuous variables expressed as grades (for example ventricular septal defect) were reordered if their effect had been shown to be nonlinear, and then re-expressed so as to improve the normality of distribution..$^{13}$ Continuous variables or derivatives thereof which had been shown to be non-linear and to have an intermediate level at which survival was maximal or minimal were squared, both the original variable and the squared variable being subsequently employed. This recoding is presented in Table 2.

Those independent variables which could usefully be used for future prediction of survival were then introduced into stepwise discriminant function analysis with the objective of distinguishing those patients who died or required definitive surgery before 6 months of age from those who survived or had definitive surgery later. This prediction was
Table 2 Recoding of discontinuous variables for entry into discriminant function analysis

\begin{tabular}{llr}
\hline Variable & State & Code \\
\hline VSD & None & -0.40 \\
& Small & -3.53 \\
PDA & Large & $2 \cdot 31$ \\
& None & -0.90 \\
& Small, ligated & $1 \cdot 11$ \\
& Small, not ligated & 1.56 \\
& Large, ligated & $2 \cdot 20$ \\
LVOTO & Large, not ligated & $4 \cdot 00$ \\
& Absent or trivial & -1.00 \\
& Moderate & 1.76 \\
& Severe & 3.45 \\
\hline
\end{tabular}

VSD, ventricular septal defect; PDA, persistent ductus arteriosus; LVOTO, left ventricular outflow tract obstruction.

based only upon data available at the time of balloon atrial septostomy. Continuous variables which had required coding for the survival analysis, and were shown to have an independent effect, were introduced as continuous variables from here on. The Statistical packaye for the social sciences programme ${ }^{14}$ was used, with prior probabilities set according to the proportion of patients in each group, and minimisation of Wilks' lambda as the criterion for preferred entry in the analysis. The cut-off level for entry or exclusion of variables was set at $F=2 \cdot 0$. The three patients having balloon atrial septostomy after 6 months of age were excluded. The discriminant function obtained in this programme is based upon casewise deletion of missing values. Consequently a combination of forward and backward stepwise regression was used, by introducing variables with the least number of missing values first, eliminating by backward regression those which were uncontributory, adding further variables and so forth.

This programme produces a classification of patients into groups according to the discriminant function obtained. In order to obtain the best estimate of the performance of this discriminant function on classification of patients whose fate is unknown, jack-knifing ${ }^{15}$ was employed, introducing the variables already selected by discriminant function analysis in a data set containing no missing values into the Genstat ${ }^{16}$ macro routine. Jackknifing consists in essence of removing one patient at a time from the analysis, and predicting his status from the discriminant function obtained from all the rest. ${ }^{13}$

\section{Results}

In presenting these results, we emphasise that to state that a variable has an effect on survival merely means that when it is introduced, it has a statistically significant effect on the calculation of survival. This 
does not imply that if all other variables were held constant, and an intervention were made so as to alter this variable and no other, that survival would necessarily be altered in the manner predicted.

\section{OVERALL PROFILE OF POPULATION STUDIED}

Of the 144 patients, $99(68.8 \%)$ had an intact ventricular septum; $11(7.6 \%)$ had a small ventricular septal defect, and $34(23.6 \%)$ had a large ventricular septal defect. Of those patients with an intact ventricular septum, seven $(7 \cdot 1 \%)$ had moderate, and three $(3.0 \%)$ had severe left ventricular outflow tract obstruction, while the corresponding figures for those with small ventricular septal defects were two $(18 \cdot 2 \%)$ and one $(9 \cdot 1 \%)$. Of the patients with large ventricular septal defects, moderate left ventricular outflow tract obstruction was present in three patients $(8.8 \%)$ and severe left ventricular outflow tract obstruction in seven $(20 \cdot 6 \%)$. Ninety-nine patients $(68 \cdot 8 \%)$ had no persistent ductus arteriosus, $22(15 \cdot 3 \%$ ) a small persistent ductus arteriosus, and $23(16.0 \%)$ a large persistent ductus arteriosus. Twelve patients $(8.3 \%)$ had an aortic coarctation, and two $(1.4 \%)$ had subaortic stenosis.

The median age at septostomy was the fourth day of life, ranging from the first day to the 10th year (six septostomies were carried out beyond the first four months of life before it was appreciated that the septum was by then too tough). Before septostomy, the systemic arterial oxygen saturation ranged from 17 to 83 per cent (median $48.2 \%$ ), whereas afterwards it ranged from 25 to 88 per cent (median $69.3 \%$ ). The base excess before balloon atrial septostomy ranged from -23 to $+8 \mathrm{mEq} / \mathrm{l}$ (median $-6.0 \mathrm{mEq} / \mathrm{l}$ ) whereas after balloon atrial septostomy it ranged from -25 to +9 (median $-6 \cdot 2 \mathrm{mEq} / \mathrm{l})$.

Thirty-one patients $(21.5 \%)$ had a palliative operation between balloon atrial septostomy and definitive surgery. Resection of coarctation with ligation of a persistent ductus arteriosus was carried out in six, and banding withcut resection of coarctation but with ligation of a persistent ductus arteriosus if needed in seven. Two patients had ligation of a persistent ductus arteriosus alone. Twelve patients had a Blalock-Hanlon operation (with a shunt in one and banding in three, noted above). Eight patients in all had a shunt operation, one after previous banding. The remaining shunts were carried out in one patient with an intact ventricular septum and trivial left ventricular outflow tract obstruction but severe cyanosis, one patient with severe left ventricular outflow tract obstruction and a small ventricular septal defect, and four patients with large ventricular septal defect and severe left ventricular outflow tract obstruction. One patient with severe left ventricular outflow tract obstruction and an intact ventricular septum had a Blalock-Hanlon septectomy and shunt.

\section{OVERALL SURVIVAL ANALYSIS}

These results will concentrate on independent variables, that is to say those whose effect could not be abolished by introduction of any other variables. Unless otherwise stated, it can be assumed that the effect of a variable is independent. Where the total number of patients is less than 144 , it is because at least one of the explanatory variables was unknown, either because the particular variable was not recorded, or else because the patient had not survived long enough for the observation to be made.

\section{FACTORS RELATING TO TIME}

Era of septostomy (Table 3)

There was a progressive improvement in survival for each three year period since $1966\left(\chi^{2}\right.$ for trend: $\mathrm{p}<0.001)$. The most pronounced difference between these eras was in survival to 6 months, which was $54.6( \pm 7.5)$ per cent in 1970-72 inclusive, $72.4( \pm 8.5)$ per cent in 1972-75 inclusive, and $86.0( \pm 5.8)$ per cent thereafter. At 18 months survival during the same eras was, respectively, $44.4( \pm 10 \cdot 0)$ per cent, $49 \cdot 8( \pm 8 \cdot 5)$ per cent, $72 \cdot 4$ $( \pm 8.5)$ per cent, and $76.5( \pm 10.4)$ per cent.

Table 3 Survival according to date of balloon atrial septostomy

\begin{tabular}{llrll}
\hline Era of septostomy & $\begin{array}{l}\text { No. of } \\
\text { patients }\end{array}$ & $\begin{array}{l}\text { Obs. } \\
\text { deaths }\end{array}$ & $\begin{array}{l}\text { Exp. } \\
\text { deaths }\end{array}$ & $O / E$ \\
\hline Before 31.12 .69 & 31 & 18 & 10.78 & 1.67 \\
1.1 .70 to 31.12 .72 & 44 & 21 & 16.14 & 1.30 \\
1.1 .73 to 31.12 .75 & 33 & 8 & 11.75 & 0.68 \\
1.1 .76 on & 36 & 6 & 14.33 & 0.42 \\
\hline $\begin{array}{l}\text { Overall } \chi^{2}=12.58 \text { on } 3 \text { d.f. } \\
\chi^{2} \text { for trend }=11.86 \text { on } 1 \text { d.f. }\end{array}$ & & $P=0.0057$ & \\
$\chi^{2}$ for non-linearity $=0.27$ on 2 d.f. & $P=0.0006$ & \\
$N=144$ & $P=0.8728$ & \\
\hline
\end{tabular}

Age at septostomy (Table 4)

At all points on the survival curve, patients having balloon atrial septostomy during the first week of life did best, followed by those having balloon atrial septostomy at the age of over 1 month. Patients having balloon atrial septostomy between 1 week and 1 month of age did worst of all.

It was possible to abolish the effect of age at septostomy by a combination of haemoglobin concentration and superior vena caval saturation after balloon atrial septostomy (Table 5). 
Table 4 Relation between age at septostomy and survival

\begin{tabular}{lllll}
\hline $\begin{array}{l}\text { Age at balloon } \\
\text { atrial septostomy }\end{array}$ & $\begin{array}{l}\text { No. of } \\
\text { patients }\end{array}$ & $\begin{array}{l}\text { Obs. } \\
\text { deaths }\end{array}$ & $\begin{array}{l}\text { Exp. } \\
\text { deaths }\end{array}$ & O/E \\
\hline < 1 wk & 88 & 25 & 34.08 & 0.73 \\
1 wk-1 mth & 27 & 16 & 7.97 & 2.01 \\
$>1$ mth & 29 & 12 & 10.95 & 1.10 \\
\hline Overall $\chi^{2}=10.84$ on 2 d.f. & & $P=0.0044$ & \\
$\chi^{2}$ for trend =2.68 on 1 d.f. & & $P=0.1017$ & \\
$\chi^{2}$ for non-linearity =7.87 on 1 d.f. & $P=0.0050$ & \\
$N=144$ & & &
\end{tabular}

Table 5 Survival and age at septostomy allowing for haemoglobin concentration at septostomy and superior vena caval saturation after septostomy

\begin{tabular}{lllll}
\hline $\begin{array}{l}\text { Age at balloon } \\
\text { atrial septostomy }\end{array}$ & $\begin{array}{l}\text { No. of } \\
\text { patients }\end{array}$ & $\begin{array}{c}\text { Obs. } \\
\text { deaths }\end{array}$ & $\begin{array}{l}\text { Exp. } \\
\text { deaths }\end{array}$ & O/E \\
\hline$<1$ week & 62 & 21 & 24.80 & 0.85 \\
1 wk-1 mth & 18 & 9 & 8.31 & 1.08 \\
$>1$ mth & 21 & 10 & 6.88 & 1.45 \\
\hline
\end{tabular}

Overall $\chi^{2}=2.55$ on 2 d.f.

$\chi^{2}$ for trend $=2 \cdot 17$ on 1 d.f.

$\chi^{2}$ for non-linearity $=$

0.03 on 1 d.f.

$$
P=0.2796
$$

$P=0 \cdot 1411$

$P=0.8566$

*Allowing for $\mathrm{Hb}$ concentration and SVC oxygen saturation after BAS.

$\mathrm{N}=101$.

\section{ANATOMICAL FACTORS}

\section{Ventricular septal defect (Table 6)}

A small ventricular septal defect was associated with a slightly lower risk than no ventricular septal defect at all, but this is of borderline significance, since though the risk with large ventricular septal defect was much higher, the test for non-linearity was not quite significant at the 5 per cent level. There were no hospital deaths in patients with small ventricular septal defects, whereas the greatest toll from large ventricular septal defects occurred in the first three months of life. At this time, survival was $82.5( \pm 3.9)$ per cent in patients without a ventricular septal defect, $90( \pm 9.5)$ per cent in those with a small defect, and $47 \cdot 1( \pm 8 \cdot 6)$ per cent in those with a large one.

Table 6 Relation between survival and ventricular septal defect

\begin{tabular}{lllll}
\hline$V S D$ & $\begin{array}{l}\text { No. of } \\
\text { patients }\end{array}$ & $\begin{array}{l}\text { Obs. } \\
\text { deaths }\end{array}$ & $\begin{array}{l}\text { Exp. } \\
\text { deaths }\end{array}$ & $O / E$ \\
\hline Absent & 99 & 29 & 37.10 & 0.78 \\
Small & 11 & 2 & 4.27 & 0.47 \\
Large & 34 & 22 & 11.63 & 1.89 \\
\hline $\begin{array}{l}\text { Overall } \chi^{2}=12.84 \text { on 2 d.f. } \\
\chi^{2} \text { for trend =9.26 on 1 d.f. }\end{array}$ & & $\mathbf{P}=0.0016$ & \\
$\chi^{2}$ for non-linearity $=$ & & $\mathrm{P}=0.0023$ & \\
3.06 on 1 d.f. & & $\mathrm{P}=0.0802$ &
\end{tabular}

Table 7 Presence of PDA and survival

\begin{tabular}{|c|c|c|c|c|}
\hline PDA & $\begin{array}{l}\text { No. of } \\
\text { patients }\end{array}$ & $\begin{array}{l}\text { Obs. } \\
\text { deaths }\end{array}$ & $\begin{array}{l}\text { Exp. } \\
\text { deaths }\end{array}$ & $O / E$ \\
\hline $\begin{array}{l}\text { Absent } \\
\text { Small } \\
\text { Large, ligated } \\
\text { Large, not ligated }\end{array}$ & $\begin{array}{r}99 \\
22 \\
16 \\
7\end{array}$ & $\begin{array}{r}27 \\
8 \\
11 \\
7\end{array}$ & $\begin{array}{r}40 \cdot 91 \\
7 \cdot 17 \\
4 \cdot 27 \\
0 \cdot 64\end{array}$ & $\begin{array}{r}0.66 \\
1.12 \\
2.58 \\
10.94\end{array}$ \\
\hline \multicolumn{2}{|c|}{$\begin{array}{l}\text { Overall } \chi^{2}=82.68 \text { on } 3 \text { d.f. } \\
\chi^{2} \text { for trend }=46.49 \text { on } 1 \text { d.f. } \\
\chi^{2} \text { for non-linearity }= \\
34.78 \text { on } 2 \text { d.f. }\end{array}$} & \multicolumn{2}{|c|}{$\begin{array}{l}P<0.0001 \\
P<0.0001 \\
P<0.0001\end{array}$} & \\
\hline
\end{tabular}

Persistent ductus arteriosus (Table 7)

In contrast to ventricular septal defect, even a small persistent ductus arteriosus had a deleterious effect on survival, and a large, unligated persistent ductus arteriosus was disastrous $(p<0.0001)$. No patient in the last group survived beyond five days. At 1 year, survival was $74.3( \pm 4.8)$ per cent in patients with no persistent ductus arteriosus, $66.5( \pm 10.4)$ per cent in patients with a small persistent ductus arteriosus, and $22.7( \pm 12.4)$ per cent when the persistent ductus arteriosus was large and ligated.

Left ventricular outflow tract obstruction (Table 8)

This had a beneficial effect regardless of the associated anomalies, in particular of the presence or absence of a ventricular septal defect. At 1 year, survival was $54.2( \pm 5.3)$ per cent in patients with no obstruction, $84.4( \pm 8 \cdot 3)$ per cent with trivial, $91.7( \pm 8.0)$ per cent with moderate, and 90.9 $( \pm 8 \cdot 7)$ per cent with severe obstruction.

\section{Right ventricular outflow obstruction}

The effects here were diametrically opposite to those of left ventricular outflow obstruction. Both patients with aortic stenosis and all six patients with untreated coarctation died. Four of six patients with resected coarctation also died $(\mathrm{p}<0.001)$.

\section{VASCULAR ACCIDENTS}

Not surprisingly, whether cerebrovascular accidents or thromboses of the abdominal aorta or its major branches, these had a very adverse effect on survival, which could not be explained, among other

Table 8 Left ventricular outflow tract obstruction and survival

\begin{tabular}{|c|c|c|c|c|}
\hline LVOTO & $\begin{array}{l}\text { No. of } \\
\text { patients }\end{array}$ & $\begin{array}{l}\text { Observed } \\
\text { deaths }\end{array}$ & $\begin{array}{l}\text { Expected } \\
\text { deaths }\end{array}$ & $O / E$ \\
\hline $\begin{array}{l}\text { Absent } \\
\text { Trivial } \\
\text { Moderate } \\
\text { Severe }\end{array}$ & $\begin{array}{r}101 \\
20 \\
12 \\
11\end{array}$ & $\begin{array}{r}46 \\
3 \\
1 \\
3\end{array}$ & $\begin{array}{r}34 \cdot 49 \\
7 \cdot 14 \\
4 \cdot 91 \\
6 \cdot 47\end{array}$ & $\begin{array}{l}1.33 \\
0.42 \\
0.20 \\
0.46\end{array}$ \\
\hline Severe & 144 & & & \\
\hline
\end{tabular}


things, by haemoglobin concentration or hypoxaemia $(p<0.0001)$.

\section{HAEMOGLOBIN CONCENTRATION}

The lower the plasma haemoglobin concentration, the poorer was the survival. This applied both at the time of balloon atrial septostomy and at the second cardiac catheterisation $(p<0.05$ for trend in both instances). The effect was particularly obvious in patients with a haemoglobin below $13.5 \mathrm{~g} / \mathrm{dl}$ at balloon atrial septostomy where at five months after balloon atrial septostomy, survival was $47 \cdot 0( \pm 9 \cdot 8)$ per cent, as opposed to $70 \cdot 0( \pm 6 \cdot 8)$ per cent for $13.5-15 \mathrm{~g} / \mathrm{dl}, 84.4( \pm 5.9)$ per cent for $15.5-18$ $\mathrm{g} / \mathrm{dl}$, and $78 \cdot 7( \pm 9 \cdot 6)$ per cent for those with above $18 \mathrm{~g} / \mathrm{dl}$. It is of particular interest that no deaths occurred in the 13 patients with a haemoglobin above $18 \mathrm{~g} / \mathrm{dl}$ at their second cardiac catheterisation.

\section{HAEMODYNAMIC STATE BEFORE BALLOON}

\section{ATRIAL SEPTOSTOMY}

Apart from the factors already mentioned, no haemodynamic variable or combination thereof was found to affect survival.

\section{HAEMODYNAMIC STATE AFTER BALLOON}

ATRIAL SEPTOSTOMY

Systemic arterial oxygen saturation and $\mathrm{PO}_{2}$

The rise in systemic arterial oxygen saturation after balloon atrial septostomy was strongly predictive of survival $(p<0.05)$, but the effect was non-linear $(p<0.05)$ (Table 9). Patients did worst if there was a rise in saturation under 15 per cent, and did better with either a higher rise, no change, or a fall in oxygen saturation. Thus at 10 months after operation, $86 \cdot 7( \pm 8.8)$ per cent of patients with no change or a fall of arterial oxygen saturation survived, as opposed to $49.2( \pm 7.5)$ per cent who had a rise of 15 per cent, $75 \cdot 4( \pm 7 \cdot 2)$ per cent with a rise of 15 to 30 per cent, and $91.1( \pm 6.0)$ per cent with a rise above 30 per cent.

On the other hand, the patients who did best had a systemic arterial $\mathrm{Po}_{2}$ between 25 and 45

Table 9 Survival and rise in $\mathrm{O}_{2}$ saturation with balloon atrial septostomy

\begin{tabular}{|c|c|c|c|c|}
\hline $\begin{array}{l}\text { Rise in } \mathrm{O}_{2} \text { saturation } \\
(B A S)\end{array}$ & $\begin{array}{l}\text { No. of } \\
\text { patients }\end{array}$ & $\begin{array}{l}\text { Obs. } \\
\text { deaths }\end{array}$ & $\begin{array}{l}\text { Exp. } \\
\text { deaths }\end{array}$ & $O / E$ \\
\hline $\begin{array}{l}\text { No change or fall } \\
<15 \% \\
15-30 \% \\
>30 \%\end{array}$ & $\begin{array}{l}15 \\
51 \\
39 \\
23\end{array}$ & $\begin{array}{r}3 \\
25 \\
10 \\
5\end{array}$ & $\begin{array}{r}5 \cdot 80 \\
15 \cdot 19 \\
13 \cdot 62 \\
8 \cdot 39\end{array}$ & $\begin{array}{l}0.52 \\
1.65 \\
0.73 \\
0.60\end{array}$ \\
\hline \multicolumn{3}{|c|}{$\begin{array}{l}\text { Overall } \chi^{2}=10.17 \text { on } 3 \text { d.f. } \\
\chi^{2} \text { for trend }=1.32 \text { on } 1 \text { d.f. } \\
\chi^{2} \text { for non-linearity }=8.66 \text { on } 2 \text { d.f. } \\
N=128\end{array}$} & $\begin{array}{l}0 \cdot 0172 \\
0 \cdot 2512 \\
0 \cdot 0132\end{array}$ & \\
\hline
\end{tabular}

$\mathrm{mmHg}$, whereas more extreme values were less well tolerated (Table 10). At six months, survival was $66.7( \pm 16.1)$ per cent for a $\mathrm{Po}_{2}$ below 25 $\mathrm{mmHg}, 86 \cdot 2( \pm 6 \cdot 4)$ per cent for between 25 and 35 mmHg, 73.6 $( \pm 7 \cdot 6)$ per cent for values between 35 and $45 \mathrm{mmHg}$, and $58.4( \pm 10.6)$ per cent when the $\mathrm{Po}_{2}$ was above $45 \mathrm{mmHg}$. The non-linearity of the response reached statistical significance in 68 patients with balloon atrial septostomy at less than one week $(p<0.02)$, but in general, adjustment for other variables, notably the presence of persistent ductus arteriosus and ventricular septal defect, abolished the effect. The arterial blood gases and interatrial gradients before and after balloon atrial septostomy could not be correlated with survival.

\section{HAEMODYNAMIC STATE AT SECOND \\ CARDIAC CATHETERISATION}

\section{Pulmonary artery systolic pressure (Table 11)}

This variable proved to be more closely correlated with survival, and more resistant to adjustment for other variables than did ratios between flows and resistances, which were not in themselves predictive in this respect. In particular, the effect was not abolished by allowance for persistent ductus arteriosus or ventricular septal defect. At eight months after balloon atrial septostomy, survival in patients with a pulmonary artery systolic pressure of less than $30 \mathrm{mmHg}$ was $94.0( \pm 2.9)$ per cent. When the pressure was 30 to $50 \mathrm{mmHg}$, survival was $92.3( \pm 7.4)$ per cent; at 50 to $70 \mathrm{mmHg}$ it was $60.0( \pm 21.9)$ per cent; and at above $70 \mathrm{mmHg}$, $40.0( \pm 21 \cdot 9)$ per cent.

\section{Systemic arterial and venous oxygen saturations}

These variables, taken alone, had an effect on survival of borderline statistical significance, but adjustment for haemoglobin concentration greatly strengthened this relation $(p<0.02$ for systemic arterial saturation, $p<0.005$ for superior vena caval saturation). The observed/expected death ratio was seven times greater for patients with a superior

Table 10 Survival and systemic arterial $\mathrm{Po}_{2}$ after septostomy

\begin{tabular}{lllrl}
\hline $\mathrm{Po}_{2}$ after $B A S$ & $\begin{array}{l}\text { No. of } \\
\text { patients }\end{array}$ & $\begin{array}{l}\text { Obs. } \\
\text { deaths }\end{array}$ & $\begin{array}{l}\text { Exp. } \\
\text { deaths }\end{array}$ & $O / E$ \\
\hline$<25 \mathrm{mmHg}$ & 10 & 3 & 2.45 & 1.22 \\
$25-35 \mathrm{mmHg}$ & 30 & 5 & 10.82 & 0.46 \\
$35-45 \mathrm{mmHg}$ & 37 & 11 & 11.52 & 0.95 \\
$>45 \mathrm{mmHg}$ & 22 & 13 & 7.20 & 1.80 \\
\hline $\begin{array}{l}\text { Overall } \chi^{2}=8.09 \text { on } 3 \text { d.f. } \\
\chi^{2} \text { for trend =4.01 on }\end{array}$ & & $\mathrm{P}=0.0442$ & \\
$\begin{array}{l}\text { 1 d.f. } \\
\chi^{2} \text { for non-linearity }=\end{array}$ & & $\mathrm{P}=0.0453$ & \\
3.67 on 2 d.f. & & $\mathrm{P}=0.1600$ & \\
$\mathrm{~N}=99$ & & &
\end{tabular}


vena caval saturation of less than 40 per cent than for patients with a saturation of greater than 40 per cent, when the effect of haemoglobin concentration was taken into account.

Putting the effect of haemoglobin concentration and oxygen saturation together by calculating systemic arterial oxygen content resulted in a significant linear correlation with survival $(p<0.05$ for trend) with the effect most obvious at nine months after balloon atrial septostomy, when survival was $74 \cdot 6$ $( \pm 8.4)$ per cent in patients with a content less than 12 vol per cent, and not less than $92.9( \pm 6.9)$ per cent whenever the content was higher. This effect was strongly reinforced when patients with right ventricular outflow tract obstruction were excluded (Table 12), and mildly reinforced when left ventricular outflow tract obstruction was allowed for. Similar results applied to systemic venous arterial content, except that the reinforcement was not so strong when patients with right ventricular outflow tract obstruction were excluded.

\section{Acid-base state at cardiac catheterisation}

It is of interest that there was a high mortality in those patients who had a base excess, three out of five patients, all deaths occurring in patients with a

Table 11 Survival and pulmonary artery systolic pressure

\begin{tabular}{lllll}
\hline PA systolic pressure & $\begin{array}{l}\text { No. of } \\
\text { patients }\end{array}$ & $\begin{array}{l}\text { Obs. } \\
\text { deaths }\end{array}$ & $\begin{array}{l}\text { Exp. } \\
\text { deaths }\end{array}$ & O/E \\
\hline$<30 \mathrm{mmHg}$ & 71 & 7 & 12.06 & 0.58 \\
$30-50 \mathrm{mmHg}$ & 13 & 3 & 1.96 & 1.53 \\
$50-70 \mathrm{mmHg}$ & 5 & 2 & 0.37 & 5.45 \\
$>70 \mathrm{mmHg}$ & 5 & 3 & 0.62 & 4.87 \\
\hline Overall $\chi^{2}=19.53$ on 3 d.f. & & $\mathrm{P}=0.0002$ & \\
$\chi^{2}$ for trend $=16.11$ on 1 d.f. & $\mathrm{P}=0.0001$ & \\
$\chi^{2}$ for non-linearity = 1.91 on 2 d.f. & $\mathrm{P}=0.3842$ & \\
$\mathrm{~N}=94$ & & &
\end{tabular}

Table 12 Survival and systemic arterial oxygen content at repeat cardiac catheterisation (patients with right ventricular outflow tract obstruction excluded)

\begin{tabular}{lllll}
\hline Oxygen content & $\begin{array}{l}\text { No. of } \\
\text { patients }\end{array}$ & $\begin{array}{l}\text { Observed } \\
\text { deaths }\end{array}$ & $\begin{array}{l}\text { Expected } \\
\text { deaths }\end{array}$ & O/E \\
\hline$<12$ vol \% & 31 & 8 & 4.04 & 1.98 \\
$12-13.5$ vol $\%$ & 29 & 5 & 3.72 & 1.34 \\
$13-15.5$ vol \% & 22 & 2 & 4.23 & 0.47 \\
$>15.5$ vol $\%$ & 13 & 0 & 3.01 & 0 \\
\hline & 95 & & &
\end{tabular}

Overall $\chi^{2}=8.88$ on 3 d.f.

$P=0.0309$

$\chi^{2}$ for trend $=8.04$ on 1 d.f.

$P=0.0046$

$\chi^{2}$ for non-linearity $=0.14$ on 2 d.f. pulmonary artery systolic pressure above $\mathbf{5 0}$ mmHg.

\section{DISCRIMINANT FUNCTION ANALYSIS \\ State at 6 months}

For this analysis, patients were withdrawn "dead" if before 6 months of age they had undergone a definitive operation, since the indication for surgery was that death was felt to be imminent. All analyses are presented for patients in whom values for all the predictive variables were recorded.

The most widely applicable discriminant function was based upon the rise in oxygen saturation produced by balloon atrial septostomy, the systemic arterial oxygen content after balloon atrial septostomy, the presence of left ventricular outflow obstruction, the presence and size of ventricular septal defect, and the presence, size, and management of persistent ductus arteriosus. The summary of the stepwise procedure and performance of the jack-knified discriminant function are shown in Table 13. The latter produced a correct prediction in $96 / 126(76.2 \%)$ of cases. From Tables 14 to 18 may be read the probability of surviving to the age of 6 months without requiring urgent definitive repair.

Table 13 Discriminant function on death or definitive repair before 6 months of age

\begin{tabular}{lllll}
\hline Step No. & $\begin{array}{l}\text { Variable } \\
\text { entered }\end{array}$ & F to enter & $\begin{array}{l}\text { Wilks } \\
\text { lambda }\end{array}$ & Significance \\
\hline 1 & PDA & 29.4 & 0.808 & $\mathrm{P}<0.0005$ \\
2 & SARCON & 11.2 & 0.740 & $\mathrm{P}<0.0005$ \\
3 & DELSA & 6.3 & 0.704 & $\mathrm{P}<0.0005$ \\
4 & LVOTO & 4.6 & 0.678 & $\mathrm{P}<0.0005$ \\
5 & VSD & 3.3 & 0.660 & $\mathrm{P}<0.0005$ \\
\hline
\end{tabular}

Death or early repair predicted if:

0.598 (PDA) -0.124 (SARCON) -0.024 (DELSA)

-0.324 (LVOTO) +0.221 (VSD) $>-1.15$.

Performance of jack-knifed function

\begin{tabular}{|c|c|c|c|c|}
\hline & & \multicolumn{3}{|l|}{ Predicted state } \\
\hline & & $\begin{array}{l}\text { Alive without } \\
\text { repair }\end{array}$ & $\begin{array}{l}\text { Dead or } \\
\text { repaired }\end{array}$ & Total \\
\hline \multirow{3}{*}{$\begin{array}{r}\text { Actual } \\
\text { state }\end{array}$} & $\begin{array}{l}\text { Alive without } \\
\text { repair }\end{array}$ & 72 & 18 & 90 \\
\hline & $\begin{array}{l}\text { Dead or } \\
\text { repaired }\end{array}$ & 12 & 24 & 36 \\
\hline & Total & 84 & 42 & 126 \\
\hline \multicolumn{5}{|c|}{$\begin{array}{l}\text { Correct prediction in } 76.2 \text { per cent overall. } \\
\text { Coding as in Table } 3 \text {. } \\
\text { DELSA, change in systemic arterial oxygen saturation on septo- } \\
\text { stomy (\%). } \\
\text { LVOTO, left ventricular outflow tract obstruction. } \\
\text { PDA, persistent ductus arteriosus. } \\
\text { SARCON, systemic arterial oxygen content after septostomy } \\
\text { (ml/100 ml). } \\
\text { VSD, ventricular septal defect. }\end{array}$} \\
\hline
\end{tabular}


Table 14 Probability of survival without "correction" to 6 months of age

Patients with no PDA

\begin{tabular}{|c|c|c|c|c|c|c|c|c|c|c|c|c|c|c|c|c|}
\hline $\begin{array}{l}\mathrm{S}_{\mathrm{A}} \mathrm{O}_{2} \text { content } \\
\text { after } \mathrm{BAS} \\
(\mathrm{ml} / 100 \mathrm{ml})\end{array}$ & & 5 & & & 10 & & & 15 & & & 20 & & & 25 & & \\
\hline & $V S D$ & & & & & & & & & & & 3 & & & & \\
\hline \multirow[t]{4}{*}{-20} & Absent & 0.25 & 0.58 & 0.76 & 0.47 & 0.70 & 0.89 & 0.70 & 0.91 & 0.95 & 0.86 & 0.96 & 0.98 & 0.94 & 0.99 & 0.99 \\
\hline & Small & 0.50 & 0.68 & 0.91 & 0.73 & 0.92 & 0.96 & 0.88 & 0.97 & 0.99 & 0.95 & 0.98 & 0.99 & 0.98 & 1.00 & 1.00 \\
\hline & Large & 0.12 & 0.35 & 0.55 & 0.26 & 0.58 & 0.77 & 0.48 & 0.71 & 0.90 & 0.7 & 0.91 & 0.96 & 0.87 & 0.96 & 0.98 \\
\hline & Absent & 0.41 & 0.74 & 0.87 & 0.65 & 0.88 & 0.95 & 0.83 & 0.95 & 0.98 & 0.93 & 0.98 & 0.99 & 0.97 & 0.99 & 1.00 \\
\hline \multirow[t]{2}{*}{0} & Small & 0.68 & 0.90 & 0.95 & 0.85 & 0.96 & 0.98 & 0.94 & 0.98 & 0.99 & 0.98 & 0.99 & 1.00 & 0.99 & 1.00 & 1.00 \\
\hline & Large & 0.22 & 0.53 & 0.72 & 0.42 & 0.75 & 0.87 & 0.66 & 0.89 & 0.95 & 0.84 & 0.95 & 0.98 & 0.93 & 0.98 & 0.99 \\
\hline \multirow[t]{3}{*}{20} & Small & 0.82 & 0.95 & 0.98 & 0.92 & 0.98 & 0.99 & 0.97 & 0.99 & 1.00 & 0.99 & 1.00 & 1.00 & 1.00 & 1.00 & 1.00 \\
\hline & Large & $0 \cdot 37$ & 0.70 & 0.85 & 0.61 & 0.86 & 0.94 & 0.80 & 0.94 & 0.98 & 0.92 & 0.98 & 0.99 & 0.97 & 0.99 & $1 \cdot 00$ \\
\hline & Absent & 0.76 & 0.93 & 0.97 & 0.89 & 0.97 & 0.99 & 0.96 & 0.99 & 1.00 & 0.98 & 1.00 & 1.00 & 0.99 & 1.00 & 1.00 \\
\hline \multirow[t]{3}{*}{40} & Small & 0.90 & 0.97 & 0.99 & 0.96 & 0.99 & $1 \cdot 00$ & 0.99 & $1 \cdot 00$ & 1.00 & 0.99 & 1.00 & $1 \cdot 00$ & 1.00 & 1.00 & 1.00 \\
\hline & Large & 0.55 & 0.83 & 0.92 & 0.76 & 0.93 & 0.97 & 0.90 & 0.97 & 0.99 & 0.96 & 0.99 & 1.00 & 0.98 & 1.00 & $1 \cdot 00$ \\
\hline & Absent & 0.87 & 0.96 & 0.98 & 0.95 & 0.99 & 1.00 & 0.98 & 1.00 & 1.00 & 0.99 & 1.00 & 1.00 & 1.00 & $1 \cdot 00$ & 1.00 \\
\hline \multirow[t]{2}{*}{60} & Small & 0.95 & 0.99 & 1.00 & 0.98 & 1.00 & 1.00 & 0.99 & 1.00 & 1.00 & 1.00 & 1.00 & 1.00 & 1.00 & 1.00 & 1.00 \\
\hline & Large & 0.72 & 0.91 & 0.96 & 0.81 & 0.97 & 0.99 & 0.95 & 0.99 & 0.99 & 0.98 & 1.00 & 1.00 & 0.99 & 1.00 & 1.00 \\
\hline
\end{tabular}

Table 15 Probability of survival without "correction" to 6 months of age

Patients with small ligated $P D A$

\begin{tabular}{|c|c|c|c|c|c|c|c|c|c|c|c|c|c|c|c|c|}
\hline $\begin{array}{l}S_{\mathrm{A}} \mathrm{O}_{2} \text { content } \\
\text { after } B A S \\
(\mathrm{ml} / 100 \mathrm{ml})\end{array}$ & & 5 & & & 10 & & & 15 & & & 20 & & & 25 & & \\
\hline \multirow[t]{3}{*}{$\begin{array}{l}\text { Rise in } S_{\mathrm{A}} O_{2} \\
\text { saturation on } \\
B A S(\%)\end{array}$} & LVOTO & $\begin{array}{l}\text { None } \\
\text { or } \\
\text { Triv }\end{array}$ & Mod & Sev & $\begin{array}{l}\text { None } \\
\text { or } \\
\text { Triv }\end{array}$ & Mod & Sev & $\begin{array}{l}\text { None } \\
\text { or } \\
\text { Triv }\end{array}$ & Mod & Sev & $\begin{array}{l}\text { None } \\
\text { or } \\
\text { Triv }\end{array}$ & Mod & Sev & $\begin{array}{l}\text { None } \\
\text { or } \\
\text { Triv }\end{array}$ & Mod & Sev \\
\hline & $V S D$ & & & & & & & & & & & & & & & \\
\hline & Absent & 0.03 & 0.12 & 0.24 & 0.08 & 0.26 & 0.46 & $0 \cdot 19$ & 0.49 & 0.69 & 0.38 & $0 \cdot 71$ & 0.85 & 0.62 & 0.87 & 0.94 \\
\hline \multirow[t]{3}{*}{-20} & Small & 0.09 & 0.29 & 0.48 & 0.21 & 0.52 & 0.71 & 0.41 & 0.73 & 0.87 & 0.65 & 0.88 & 0.95 & 0.83 & 0.95 & 0.98 \\
\hline & Large & 0.01 & 0.05 & $0 \cdot 11$ & 0.03 & 0.12 & 0.25 & 0.08 & 0.26 & 0.46 & $0 \cdot 19$ & 0.49 & $0 \cdot 70$ & 0.39 & 0.72 & 0.86 \\
\hline & Absent & 0.07 & 0.22 & 0.40 & 0.16 & 0.43 & 0.64 & 0.33 & 0.67 & 0.82 & 0.56 & 0.84 & 0.93 & $0 \cdot 77$ & 0.93 & 0.97 \\
\hline \multirow[t]{3}{*}{0} & Small & $0 \cdot 17$ & 0.46 & 0.66 & 0.35 & 0.69 & 0.84 & 0.59 & 0.86 & 0.93 & $0 \cdot 79$ & 0.94 & 0.97 & 0.91 & 0.97 & 0.99 \\
\hline & Large & 0.03 & $0 \cdot 10$ & 0.21 & 0.07 & 0.23 & 0.41 & $0 \cdot 16$ & 0.44 & 0.65 & 0.34 & 0.67 & 0.83 & 0.57 & 0.85 & 0.93 \\
\hline & Absent & 0.28 & 0.61 & 0.59 & 0.51 & 0.62 & 0.91 & 0.73 & 0.92 & 0.96 & 0.88 & 0.97 & 0.99 & $0 \cdot 88$ & 0.97 & 0.99 \\
\hline \multirow[t]{3}{*}{20} & Small & 0.54 & 0.83 & 0.92 & 0.75 & 0.93 & 0.97 & 0.89 & 0.97 & 0.99 & 0.96 & 0.99 & 1.00 & 0.96 & 0.99 & 1.00 \\
\hline & Large & 0.13 & 0.38 & $0 \cdot 79$ & 0.29 & 0.81 & 0.79 & 0.52 & 0.81 & 0.91 & 0.74 & 0.92 & 0.96 & 0.74 & 0.92 & 0.96 \\
\hline & Absent & 0.24 & 0.56 & 0.75 & 0.45 & 0.77 & 0.89 & 0.69 & 0.90 & 0.95 & 0.85 & 0.96 & 0.98 & 0.94 & 0.98 & 0.99 \\
\hline \multirow[t]{3}{*}{40} & Small & 0.48 & 0.79 & 0.90 & 0.71 & 0.91 & 0.96 & 0.87 & 0.97 & 0.98 & 0.95 & 0.99 & 0.99 & 0.98 & 1.00 & 1.00 \\
\hline & Large & $0 \cdot 11$ & 0.33 & 0.54 & 0.21 & 0.57 & 0.75 & 0.46 & 0.78 & 0.89 & 0.69 & 0.90 & 0.96 & 0.86 & 0.96 & 0.98 \\
\hline & Absent & 0.44 & 0.73 & 0.86 & 0.63 & 0.88 & 0.94 & 0.82 & 0.95 & 0.98 & 0.92 & 0.99 & 0.99 & 1.00 & 0.99 & 1.00 \\
\hline \multirow[t]{2}{*}{60} & Small & 0.66 & 0.89 & 0.95 & 0.84 & 0.96 & 0.98 & 0.93 & 0.98 & 0.99 & 0.97 & 0.99 & 1.00 & 0.99 & 1.00 & 1.00 \\
\hline & Large & 0.20 & 0.51 & 0.71 & 0.40 & 0.73 & 0.87 & 0.64 & 0.88 & 0.95 & 0.83 & 0.95 & 0.98 & 0.93 & 0.98 & 0.99 \\
\hline
\end{tabular}


Table 16 Probability of survival without "correction" to 6 months of age

Patients with small unligated PDA

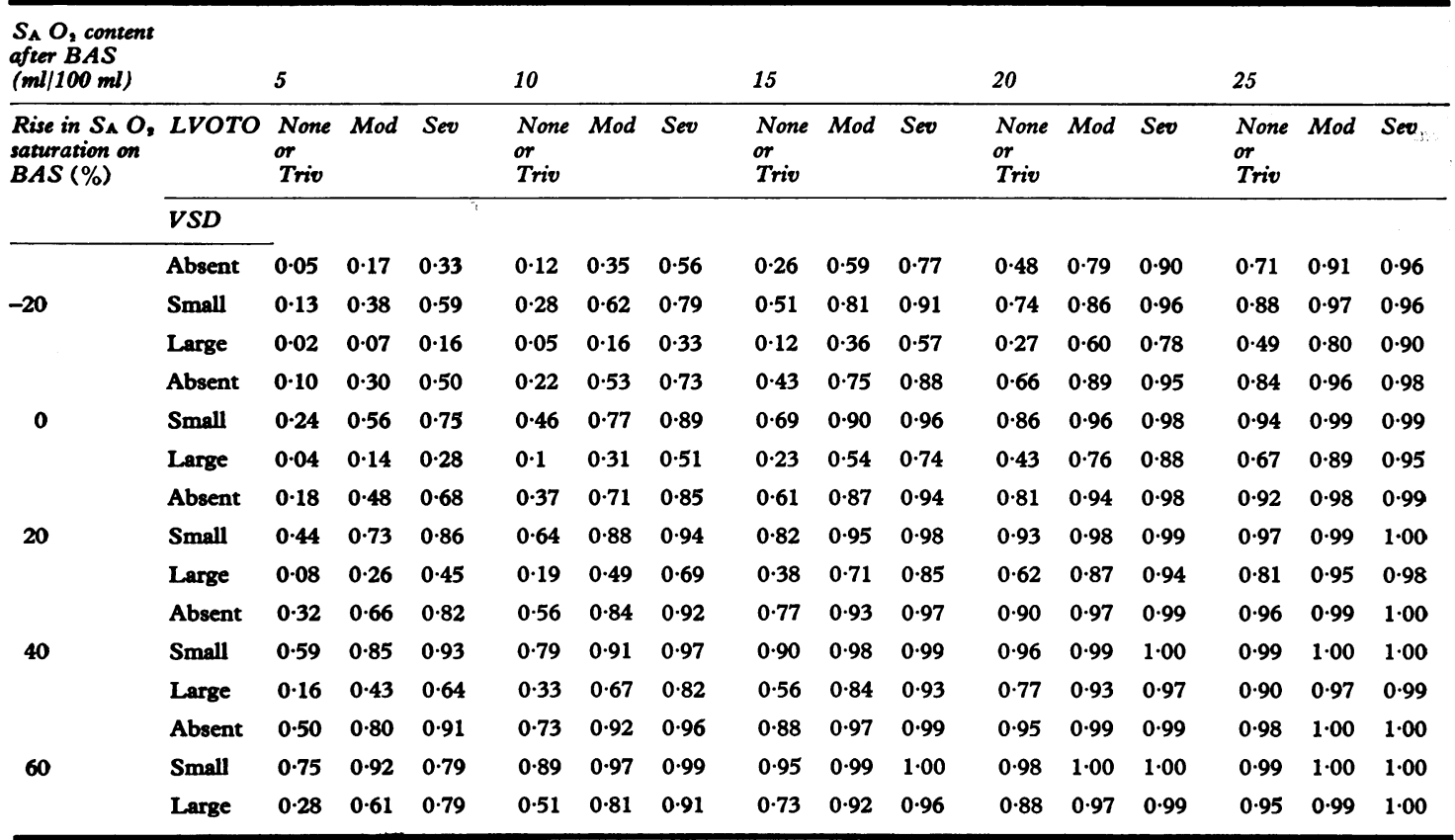

Table 17 Probability of survival without "correction" to 6 months of age

Patients with large ligated $P D A$

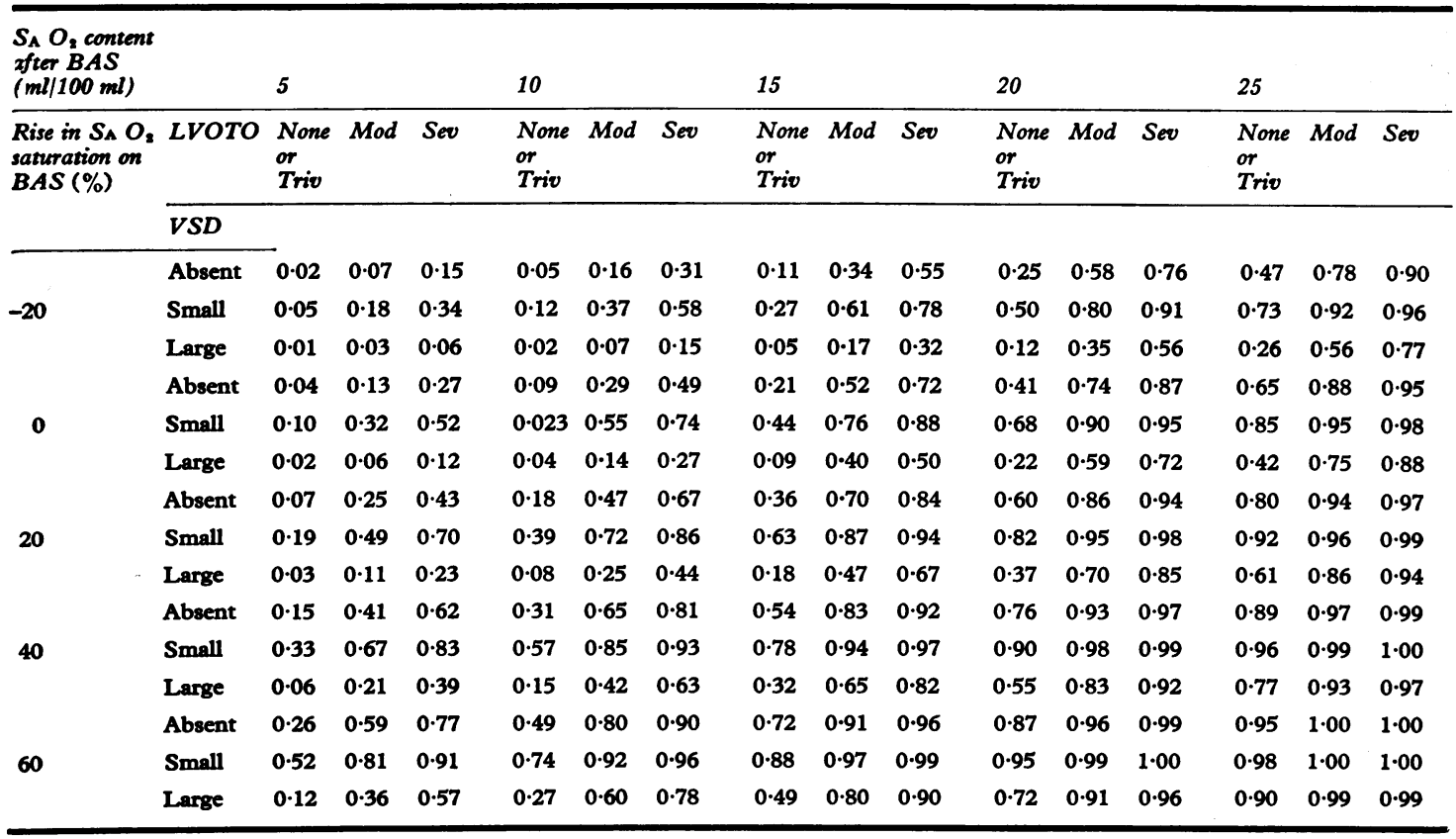


Table 18 Probability of survival without "correction" to 6 months of age

Patients with large unligated PDA

\begin{tabular}{|c|c|c|c|c|c|c|c|c|c|c|c|c|c|c|c|c|}
\hline $\begin{array}{l}S_{\mathrm{A}} \mathrm{O}_{2} \text { content } \\
\text { after } \mathrm{BAS} \\
(\mathrm{ml} / 100 \mathrm{ml})\end{array}$ & & 5 & & & 10 & & & 15 & & & 20 & & & 25 & & \\
\hline \multirow[t]{2}{*}{$\begin{array}{l}\text { Rise in } S_{\mathrm{A}} \mathrm{O}_{2} \\
\text { saturation } \\
\text { on } B A S(\%)\end{array}$} & LVOTO & $\begin{array}{l}\text { None } \\
\text { or } \\
\text { Triv }\end{array}$ & Mod & Sev & $\begin{array}{l}\text { None } \\
\text { or } \\
\text { Triv }\end{array}$ & Mod & Sev & $\begin{array}{l}\text { None } \\
\text { or } \\
\text { Triv }\end{array}$ & Mod & Sev & $\begin{array}{l}\text { None } \\
\text { or } \\
\text { Triv }\end{array}$ & Mod & Sev & $\begin{array}{l}\text { None } \\
\text { or } \\
\text { Triv }\end{array}$ & Mod & Sev \\
\hline & \multicolumn{16}{|l|}{$V S D$} \\
\hline \multirow{3}{*}{-20} & Absent & 0.00 & 0.01 & 0.03 & 0.01 & 0.04 & 0.08 & 0.02 & 0.09 & $0 \cdot 18$ & 0.06 & 0.20 & 0.37 & 0.14 & 0.40 & 0.61 \\
\hline & $\begin{array}{l}\text { Small } \\
\text { Large }\end{array}$ & $\begin{array}{l}0.01 \\
0.00\end{array}$ & $\begin{array}{l}0.04 \\
0.01\end{array}$ & $\begin{array}{l}0.09 \\
0.01\end{array}$ & $\begin{array}{l}0.03 \\
0.00\end{array}$ & $\begin{array}{l}0.10 \\
0.01\end{array}$ & $\begin{array}{l}0.20 \\
0.03\end{array}$ & $\begin{array}{l}0.07 \\
0.01\end{array}$ & $\begin{array}{l}0.22 \\
0.04\end{array}$ & $\begin{array}{l}0.4 \\
0.08\end{array}$ & $\begin{array}{l}0.16 \\
0.02\end{array}$ & $\begin{array}{l}0.43 \\
0.09\end{array}$ & $\begin{array}{l}0.64 \\
0.17\end{array}$ & $\begin{array}{l}0.33 \\
0.06\end{array}$ & $\begin{array}{l}0.67 \\
0.21\end{array}$ & 0.82 \\
\hline & Absent & 0.01 & 0.03 & 0.06 & 0.02 & 0.07 & 0.15 & 0.05 & 0.17 & 0.32 & 0.12 & 0.35 & 0.55 & 0.26 & 0.58 & 0.77 \\
\hline \multirow[t]{3}{*}{0} & Small & 0.02 & 0.08 & $0 \cdot 17$ & 0.05 & 0.18 & 0.35 & 0.13 & 0.37 & 0.58 & 0.28 & 0.61 & 0.79 & 0.51 & 0.81 & 0.91 \\
\hline & Large & 0.00 & 0.01 & 0.03 & 0.01 & 0.03 & 0.06 & 0.02 & 0.07 & $0 \cdot 15$ & 0.05 & $0 \cdot 17$ & 0.33 & $0 \cdot 12$ & 0.35 & 0.56 \\
\hline & Absent & 0.02 & 0.06 & 0.12 & 0.04 & $0 \cdot 14$ & 0.27 & 0.09 & 0.30 & 0.50 & 0.22 & 0.53 & 0.72 & 0.42 & 0.75 & 0.87 \\
\hline \multirow[t]{2}{*}{20} & Small & 0.04 & 0.15 & 0.30 & $0 \cdot 10$ & 0.32 & 0.53 & 0.24 & 0.56 & 0.75 & 0.45 & 0.77 & 0.89 & 0.68 & 0.90 & 0.95 \\
\hline & Large & 0.01 & 0.02 & 0.05 & 0.02 & 0.06 & $0 \cdot 13$ & 0.04 & 0.14 & 0.28 & 0.10 & 0.30 & 0.51 & 0.22 & 0.54 & 0.73 \\
\hline \multirow[t]{3}{*}{40} & Small & 0.09 & 0.27 & 0.47 & 0.20 & 0.50 & 0.70 & 0.39 & 0.73 & 0.86 & 0.63 & 0.88 & 0.94 & 0.82 & 0.95 & 0.98 \\
\hline & Large & 0.01 & 0.05 & $0 \cdot 10$ & 0.03 & $0 \cdot 12$ & 0.23 & 0.08 & 0.26 & 0.45 & 0.18 & 0.48 & 0.68 & 0.37 & 0.71 & 0.85 \\
\hline & Absent & 0.06 & $0 \cdot 21$ & 0.39 & 0.15 & 0.41 & 0.62 & 0.32 & 0.65 & 0.82 & 0.55 & 0.83 & 0.92 & 0.76 & 0.93 & 0.97 \\
\hline \multirow[t]{2}{*}{60} & Small & $0 \cdot 16$ & 0.40 & 0.65 & $0 \cdot 15$ & 0.34 & 0.83 & 0.58 & 0.85 & 0.93 & 0.78 & 0.94 & 0.97 & 0.91 & 0.98 & 0.99 \\
\hline & Large & 0.03 & 0.09 & 0.20 & 0.06 & 0.22 & 0.39 & $0 \cdot 15$ & 0.42 & 0.63 & $0 \cdot 32$ & 0.66 & 0.82 & 0.56 & 0.84 & 0.92 \\
\hline
\end{tabular}

\section{Discussion}

Complete transposition of the great arteries occurs once in somewhere between 2130 and 4500 live births. ${ }^{17}$ Our best knowledge of its natural history without balloon atrial septostomy comes from the Californian necropsy study covering the years 1957-64.17 Even so, at that time the study was of unnatural history, inasmuch as 110 of the 669 deaths occurred after operation. Liebman and colleagues $^{17}$ found that in the whole group of 655 children (which included a few patients with univentricular hearts and mitral atresia), 28.7 per cent were dead by 1 week of life, 51.6 per cent by 1 month of life, and 89.3 per cent by 1 year. In the subset of 290 patients seen in the cardiac centres the overall prognosis was slightly better, but in patients with no ventricular septal defect or a ventricular septal defect of less than $3 \mathrm{~mm}$ in diameter, and no atrial septal defect, for example, 24.4 per cent were dead by 1 week, 66.1 per cent by 1 month, and 98.4 per cent by 1 year. The authors confirmed previous observations ${ }^{1819}$ as to the beneficial effects on survival of an atrial or ventricular septal defect, and the deleterious effects of a persistent ductus arteriosus. ${ }^{19}$ Left ventricular outflow tract obstruction was shown to improve survival in association with ventricular septal defect. Statistical tests, however, of the significance of these differences were not attempted, and of course physiological, as opposed to anatomical, information was infrequently available, and not analysed.

A study such as ours has the major advantage that it is prospective in the sense that entry to it is towards the beginning of life rather than at death. We cannot, of course, eliminate the effects of operation on the course of the disease after balloon atrial septostomy. We have reduced as far as possible, however, the problem of definitive surgery by looking at the data in two ways, either counting patients as alive or dead when they reached definitive surgery. Palliative surgery was not treated thus, but in any case was only used in a minority of patients $(21.5 \%)$.

Balloon atrial septostomy has been shown to have a dramatic beneficial effect on survival. ${ }^{2-9} 20$ Equally, it fails to prevent a great many deaths in early life, which is why our hospital adopted a policy of elective definitive repair in the second six months of life. ${ }^{2}$ But even this policy failed to help the 15 to $\mathbf{4 0}$ per cent who died within the first six months. The emergency intra-atrial baffle operation $^{21}$ is one answer to this problem, but carries a higher risk than elective operation, and does not deal with sudden unexpected deaths, which are not uncommon. ${ }^{23}$ What is therefore needed is some way of predicting the outcome in advance, so that surgery can be carried out electively in appropriate patients. But so far, this has not been tried. Indeed, even when attempts to identify "risk factors" were made, they usually failed. Hawker and colleagues, ${ }^{5}$ using univariate analysis, did have some success, and found a significantly better prognosis in patients with either a high interatrial pressure gradient or a high systemic arterial oxygen saturation in the absence of a ventricular septal defect. But both of 
these applied to the situation before balloon atrial septostomy. They could not correlate survival with the situation after balloon atrial septostomy. By contrast, we have not been able to show any relation between survival and factors existing before balloon atrial septostomy which can be altered by it, whereas the state of several of those factors after this procedure strongly affected survival. This incidentally indicates that no patient is too sick to benefit from balloon atrial septostomy.

Prognosis depends on many factors. It follows that unless multivariate analysis is used, the subtleties of some actions, and the interaction between different factors will lead to masking of the effects of some of them. But the disadvantage of multivariate analysis is that interpretation of the results can be so difficult. This is the reason for our somewhat laborious statistical methodology. The modified Mantel-Haenszel test was used to identify which factors influenced overall survival and how they interacted. Multivariate discriminant function analysis was simply used as an empirical method of predicting survival at 6 months. A variable will not be selected in that analysis unless it is correlated with survival. But which particular variables are selected depends on a multitude of other factors, such as how often that variable was measured, what the interaction with other variables was, and how and whether it was transformed. Consequently, the results of the discriminant function analysis should not be used as a guide to which factors are most important, and the individual discriminant coefficients should not be taken to indicate either the direction or magnitude of the effect. ${ }^{13}$

The lesions associated with transposition of the great arteries appear to affect overall survival greatly. The malignant nature of a persistent ductus arteriosus has been repeatedly shown in previous necropsy ${ }^{1819}$ and clinical ${ }^{22}$ reports. But action to rectify this has been inhibited by the argument that patients dying in the first few days of life are bound to have a large normally patent ductus which may not have contributed to death at all. ${ }^{8}$ Our results indicate that some of the apparent effect of persistent ductus may be spurious, since those patients with a large persistent ductus arteriosus did indeed die within five days. On the other hand this explanation cannot possibly account for the excess of deaths in patients with a small persistent ductus arteriosus or a ligated large persistent ductus arteriosus, since the majority of these occurred long after physiological and indeed anatomical closure of the ductus should have occurred. Presumably persistent ductus arteriosus increases volume overload of the left ventricle without adequate compensation in terms of improved mixing.

Interestingly, a small ventricular septal defect actually improved survival. This may mean that improved mixing was obtained at a lower cost, since shunting into the pulmonary circuit could occur before aortic valve opening, that is at a lower pressure. A large ventricular septal defect carried a heavy toll because in the majority of cases this was not associated with left ventricular outflow tract obstruction.

The deleterious effect of right ventricular obstruction is hardly surprising since the right ventricle has to support the systemic circulation. It is interesting, however, that two patients who died had subaortic stenosis, which is rare in complete transposition of the great arteries.

The deleterious effect of right ventricular outflow tract obstruction contrasts interestingly with the beneficial effects of left ventricular outflow tract obstruction. While the latter effect has been previously documented in necropsy studies, ${ }^{18-19}$ these can be criticised on the grounds that haemodynamically significant left ventricular outflow tract obstruction may be difficult or impossible to recognise at necropsy. The fact that left ventricular outflow tract gradients were documented haemodynamically in the majority of patients in this study adds weight to the previous necropsy studies. Furthermore, the effect of left ventricular outflow tract obstruction could not be abolished by allowing for the presence or absence of a ventricular septal defect. This indicates that though specific varieties of left ventricular outflow tract obstruction with intact ventricular septum may cause harm, ${ }^{23-25}$ the general effect is beneficial. It should be noted, however, that shunts were carried out in six patients with severe left ventricular outflow tract obstruction, five of whom had a ventricular septal defect and one of whom had an intact ventricular septum.

Two haemodynamic factors dominate prognosis, oxygen transport and pulmonary artery pressure. Effective pulmonary and systemic flow were not measured, because oxygen uptake was not measured but systemic venous oxygen saturation does reflect effective flow, ${ }^{26} 27$ so it is not surprising that the higher the systemic venous oxygen content at the second cardiac catheterisation, the better the chance of survival. This effect, however, was probably not as important as that of systemic arterial content, which of course depends on both systemic arterial oxygen saturation and haemoglobin concentration. These two constituents are mutually supportive, and yet distinct, in that the beneficial effect of a high haemoglobin concentration either at balloon atrial septostomy or at the second cardiac catheterisation was independent of either systemic 
arterial oxygen saturation or $\mathrm{Po}_{2}$. In view of the commonly expressed concern at the deleterious effect of a high haemoglobin concentration (increased blood viscosity, cerebrovascular accidents, and so forth), it is salutary to notice that no deaths at all occurred in patients with a haemoglobin concentration above $18 \mathrm{~g} / \mathrm{dl}$ at the second cardiac catheterisation. While it can be argued that this was because a high haemoglobin concentration may have hastened the date of definitive surgery, the poor outlook for patients with a haemoglobin concentration below $13.5 \mathrm{~g} / \mathrm{dl}$ at balloon atrial septostomy cannot be attributed to this mechanism nor, incidentally, to the age at balloon atrial septostomy. Furthermore, the severe effect on survival of vascular accidents, whether in the brain or elsewhere, could not be explained by the haemoglobin concentration at either cardiac catheterisation.

The relation between arterial oxygen saturation, or $\mathrm{Po}_{2}$ and survival is not straightforward because of the tendency for high arterial $\mathrm{Po}_{2}$ to be associated with persistent ductus arteriosus and ventricular septal defects. The optimal $\mathrm{Po}_{2}$ after balloon atrial septostomy was 25 to $45 \mathrm{mmHg}$. Above this the benefits were outweighed by the costs of volume overload and pulmonary hypertension. Below this, hypoxia was presemably too severe.

While a high systemic arterial oxygen content is beneficial, a high pulmonary artery systolic pressure is not, and it is of considerable interest that this effect could not be abolished by consideration of any anatomical features (notably persistent ductus arteriosus and a ventricular septal defect) either singly or in combination. In other words, pulmonary hypertension per se appears harmful. This in turn suggests that the beneficial effect of left ventricular outflow tract obstruction is not just (partly or totally) because of the consequent reduction of pulmonary blood flow, but because of the resultant fall in pulmonary artery pressure.

The effect of age at balloon atrial septostomy is striking. We interpret the higher survival in those having balloon atrial septostomy at under a week or over a month as being because the former group needed balloon atrial septostomy and received it in good time, whereas the latter group probably had relatively little need for septostomy. Lack of need for septostomy probably also explains the otherwise surprising fact that patients who had a fall in oxygen saturation at balloon atrial septostomy did rather better than those with a rise less than 1 per cent. The group between a week and a month probably needed septostomy but did not benefit so much from it as younger neonates. Though it seems no more difficult to tear the septum at 1 week than at 1 month, it may be that a more generous defect results from early septostomy. Certainly the fact that this age effect could be abolished by considering the haemoglobin concentration and superior vena caval saturation after septostomy indicates that the 1 week to 1 month group ended up with lower effective pulmonary and systemic flows.

Weight gain was studied because it was felt that poor weight gain or even weight loss might antedate death. Though gross failure to thrive may have precipitated earlier definitive surgery in some patients, our negative results suggest that the answer to predicting death does not lie in the weight chart.

The steady increase in survival over the years is gratifying, but not immediately explicable. In part, it is the result of a greater readiness to perform definitive surgery within the first six months, but this cannot explain the steady improvement in survival within a month of balloon atrial septostomy. Nor could the latter be explained by age at septostomy or condition at septostomy as judged by acid-base status. Balloon septostomy is not technically difficult, so we doubt if an improvement in technique has produced this change. The most important reason is probably the recognition that intensive care before and after septostomy is as important as before and after any surgical operation. We have also tended to limit investigation at the time of balloon atrial septostomy to the minimum necessary to establish the diagnosis of transposition of the great arteries. After balloon atrial septostomy its adequacy is checked, and then, only if the condition of the baby is blameless, and there is a strong indication for further investigation, such as suspected pulmonary hypertension or coarctation, if further catheter manipulation or angiocardiography carried out.

As already indicated, we cannot assume that because a factor has a statistically significant effect on survival, that alteration of that factor will alter survival in the manner predicted. We think it likely, however, that four measures would improve overall survival in patients with transposition of the great arteries. First, continued emphasis on the need for earlier referral would mean a higher proportion of balloon septostomies carried out in the first week of life. Second, every effort should be made to maintain haemoglobin levels at above normal levels, by iron supplements and transfusion if necessary, particularly at the time of cardiac catheterisation, because it seems that relative anaemia is much more dangerous than polycythaemia. Third, the presence of a persistent ductus arteriosus of any size should be taken seriously particularly when associated with ventricular septal defect, and ligation carried out, provided that balloon septostomy is adequate. Interatrial repair at the same time may be 
appropriate for patients with a large patent ductus arteriosus, but we are not certain on this point. A routine cardiac catheterisation at 3 months of age enables a persistent ductus arteriosus to be distinguished from a physiologically patent ductus arteriosus present in the first few days of life. Evidence for the adequacy of balloon atrial septostomy at the time of cardiac catheterisation is equalisation of mean atrial pressures with a significant rise in arterial or mixed venous oxygen saturation, but of course it sometimes happens that an initially adequate septostomy is later suspected of being inadequate. Subxiphoid real time twodimensional echocardiography may be very helpful here, as it enables the atrial septal defect to be visualised. ${ }^{28}$ It could be argued that our results show a need for the wider use of atrial septectomy, but as our experience is that this improves little, if at all, on balloon septostomy, ${ }^{2}$ we have preferred to rely on earlier interatrial repair in the management of the severely hypoxic infant. This leads us to the fourth way of improving overall survival, which is to carry out earlier definitive operation in patients identified as being at particular risk of dying within early infancy. The tables provided should help in this respect. Two-thirds of deaths are correctly predicted, and a small proportion of patients survive despite prediction of death. The method is imperfect, though it could perhaps be improved by more systematic recording of the risk factors we have identified. Nevertheless, to demand anything like perfect prediction is quite unrealistic, and to know the probability of death within a certain period should lead in time to a more rational overall treatment programme for patients with this serious disease.

We would like to express our gratitude to $\operatorname{Dr} A \mathrm{~S}$ Nadas for his comments.

\section{References}

1 Rashkind WJ, Miller WW. Creation of an atrial septal defect without thoracotomy. $\mathcal{F} A M A$ 1966; 196: 991-2.

2 Tynan M. Survival of infants with transposition of great arteries after balloon atrial septostomy. Lancet 1971 ; 1 : 621-3.

3 Parsons CG, Astley R, Burrows FGO, Singh SP. Transposition of great arteries. A study of 65 infants followed for 1 to 4 years after balloon septostomy. Br Heart $\mathfrak{f} 1971$; 33: 725-31.

4 Parisi L, Fyler DG. Management of transposition of the great arteries in New England (abstract). Am $\mathcal{f}$ Cardiol 1973; 31: 151.

5 Hawker RE, Krovetz LJ, Rowe RD. An analysis of prognostic features in the outcome of balloon atrial septostomy for transposition of the great arteries. fohns Hopkins Med f 1974; 134 : 95-106.
6 Gutgesell HP, McNamara DG. Transposition of the great arteries. Results of treatment with early palliation and late intracardiac repair. Circulation 1975; 51 : 32-8.

7 Kidd BSL. The fate of children with transposition of the great arteries following balloon atrial septostomy. In: Kidd BSL, Rowe RD, eds. The child with congenital heart disease after surgery. New York: Futura, 1976: 153-64.

8 Paul MH. D-transposition of the great arteries. In: Moss AJ, Adams FH, Emmanouilides GC, eds. Heart disease in infants, children and adolescents. Baltimore: Williams \& Wilkins, 1977: 301-38.

9 Gutgesell HP, Garson A, McNamara DG. Prognosis for the newborn with transposition of the great arteries. Am f Cardiol 1979; 44: 96-100.

10 Tynan MJ, Becker AE, Macartney FJ, QueroJiménez M, Shinebourne EA, Anderson RH. Nomenclature and classification of congenital heart disease. $\mathrm{Br}$ Heart $\mathcal{F} 1979$; 41 : 544-53.

11 Mantel N, Haenszel W. Statistical aspects of the analysis of data from retrospective studies of disease. f Natl Cancer Inst 1959; 22: 719-48.

12 Peto R, Pike MC, Armitage P, et al. Design and analysis of randomized clinical trials requiring prolonged observation of each patient. II Analysis and examples. Br $\mathcal{F}$ Cancer 1977; 35: 1-39.

13 Mosteller F, Tukey JW. Data analysis and regression. Reading, Massachusetts: Addison-Wesley, 1977.

$14 \mathrm{Nie} \mathrm{NH}$, Hull CH, Jenkins JG, Steinbrenner K, Bent DH. Statistical package for the social sciences. 2nd ed. New York: McGraw-Hill, 1975.

15 Lachenbruch PA. Evaluating a discriminant function. In: Discriminant analysis. New York: Macmillan, 1975; 25-39.

16 Alvey HG, Banfield CF, Baxter RI, et al. In: Genstat-A general statistical program. Harpenden, Herts: The Statistics Department, Rothamsted Experimental Station, 1977.

17 Liebman J, Cullum L, Belloc NB. Natural history of transposition of the great arteries. Anatomy and birth and death characteristics. Circulation 1969; 40: 237-62.

18 Gasul BM, Arcilla RA, Lev M. Transposition of the great vessels. In: Heart disease in children. Diagnosis and treatment. Philadelphia \& Montreal: Lippincott, 1966. 517-71.

19 Van Praagh R, Vlad P, Keith JD. Complete transposition of the great arteries. In: Keith JD, Rowe $\mathrm{RD}$, Vlad $\mathrm{P}$, eds. Heart disease in infancy and childhood. 2nd ed. New York: Macmillan, 1967: 682-744.

20 Clarkson PM, Barratt-Boyes BG, Neutze JM, Lowe JB. Results over a ten-year period of palliation followed by corrective surgery for complete transposition of the great arteries. Circulation 1972; 45: 1251-8.

21 Stark J, de Leval M, Waterston DJ, Bonham-Carter RE. Current surgical management of transposition of great arteries in infancy (abstract). $\mathrm{Br}$ Heart $\mathfrak{f}$ $1975 ; 37: 553$.

22 Rashkind WJ. Transposition of the great arteries: 
before the Mustard operation. Ten years' experience with balloon atrioseptostomy at the Children's Hospital of Philadelphia. In: Kidd BSL, Rowe RD, eds. The child with congenital heart disease after surgery. New York: Futura, 1976: 149-52.

23 Tynan M, Carr I, Graham G, Bonham-Carter RE. Subvalvar pulmonary obstruction complicating the postoperative course of balloon atrial septostomy in transposition of the great arteries. Circulation 1969; 39 \& 40, suppl I: 223-8.

24 Tynan M. Haemodynamic effects of balloon atrial septostomy in infants with transposition of the great arteries. Br Heart $\mathcal{F} 1972$; 34; 791-4.

25 Sansa M, Tonkin IL, Bargeron LM Jr, Elliott LP. Left ventricular outflow tract obstruction in transposition of the great arteries: an angiographic study of 74 cases. Am $\mathcal{F}$ Cardiol 1979; 44: 88-95.
26 Mair DD, Ritter DG. The physiology of cyanotic congenital heart disease. Int Rev Physiol 1976; 9: 275-303.

27 Macartney FJ. Heart and circulation. In: Godfrey S, Baum JD, eds. Clinical paediatric physiology. London: Blackwell Scientific Publications, 1979: 284-320.

28 Bierman FZ, Williams RG. Subxiphoid twodimensional imaging of the interatrial septum in infants and neonates with congenital heart disease. Circulation 1979; 60: 80-90.

Requests for reprints to Professor F J Macartney, The Hospital for Sick Children, Great Ormond Street, London WCIN 3JH. 